ГОРАН МУСИЋ и ПРЕДРАГ ВУКЧЕВИЋ

Универзитет у Грацу, Zentrum für Südosteuropastudien, Грац, Аустрија

DOI 10.5937/kultura1962166M

УДК 316.72:78.067.26(497.11)"199/..."

316.723(497.11)"199/..."

стручни рад

\title{
DIESEL POWER
}

\section{ХИП-ХОП У СРБИЈИ ОД ЗАДОВОЉСТВА ПОВЛАШКЕНИХ ДО МАСОВНЕ ОМЛАДИНСКЕ КУЛТУРЕ}

Сажетак: Најранији производи хип-хоп културе су дошли до Сочијалистичке Федеративне Републике Југославије у првој половини 1980-их, у исто време када пристижу и у Западну Европу. Па ипак, хип-хоп, схваћен као заокружени животни стил, етаблирао се као засебна поткултура унутар уског слоја урбане средњекласне омладине тек раних 90-их уз помоћ сателитске телевизије, страних магазина и пиратских касета. Неких петнаест година касније хип-хоп је постао једна од најраспрострањенијих омладинских култура у Србији. Циь овог чланка јесте да истражси ову еволиију показујући на који начин су све шири кругови омладине из различитих другтввених слојева усвајали хип-хоп, истовремено надограђујући нова, локална значења на увезену културу. Чланак аргументиие у корист тезе да је ширете хип-хопа омогућено прихватањем шареноликог локалног наслеђа турбо-фолка, фанк утииаја у популарној музиџи и урбане ромске културе. Реперско опонашане стила облачења, сленга и става дизелаша - поткултуре младих из раних 1990-их која је промовисала криминални жсивотни стил- представљено је као пример.

Кључне речи: хип-хоп, Југославија, Србија, турбо-фолк, реп, дизелаши

У настојању да се анализирају локалне манифестације хип-хопа као глобалног феномена, упутно је кренути од једноставног препознавања чињенице да је ту културу у гетима Сједињених Америчких Држава створила и уобличила омладина расних мањина која је припадала нижим 
друштвеним слојевима. ${ }^{1}$ Попут многих ранијих музичких стилова и производа америчке популарне културе, хип-хоп je у друге државе стигао као културни трансфер. Уобичајена је претпоставка да се друштвена позиција и културна значења која је хип-хоп задобио у САД аутоматски пресликавају на страни која прима културу. Хип-хоп се опажа као универзални језик потлачених. ${ }^{2}$ У периферним друштвима, међутим, у најбољој позицији за усвајање најновијих западњачких културних извозних производа је обично омладина са привилегованим друштвеним пореклом, а не она из маргинализованих група. У друштвима која је примају, хип-хоп култура може задобити нове вредности и друштвене интерпретације, веома другачије од оних које је отеловљавала у матичној земљи.

У овом поглављу се разматра промена и ширење хип-хоп израза у Србији током три деценије - у друштву које пролази преображај из државног социјализма у капитализам и у којем се хип-хоп развио од поткултуре на коју је права полагао и љубоморно чувао узак круг друштвено повлашћених следбеника реп музике, до једне од најпопуларнијих култура међу младима у Србији. Поменуто ширење је делом омогућено повезивањем хип-хопа са другим, аутентичнијим локалним културама младих. Главне прекретнице на том путу биле су: 1) Иницијално ширење хип-хопа на постојећој диско/фанк сцени и његова кохабитација са локалним поткултурним традицијама током 1980-их; 2) Еволуција хип-хопа као засебне поткултуре усмерене на уличне теме са прихватањем поджанра и моде „џи-фанка” (енг. G Funk) током 90-их; и, коначно, 3) Његова пуна еманципација у један од преферираних начина изражавања локалне омладине радничке класе крајем века кроз отворену размену са омладинском културом дизелаша, која се традиционално повезује са турбо-фолком, ,jуроденс" музиком (енг. Eurodance) и уличним криминалом.

1 Овај текст је оригинално објављен у зборнику Hip Hop at Europe's Edge: Music, Agency and Social Change под називом Diesel Power: Serbian Hip Hop from the Pleasure of the Privileged to Mass Youth Culture, а у овом броју Културе појављује се захваљујући љубазности Indiana University Press. Текст је на српски језик превео Предраг Вукчевић; Musić, G. and Vukčević, P. Diesel Power: Serbian Hip Hop from the Pleasure of the Privileged to Mass Youth Culture, in: Hip Hop at Europe's Edge: Music, Agency and Social Change, eds. Miszcynski, M. and Helbig, A. (2017), Bloomington, IN: Indiana University Press, pp. 85-108.

2 Osumare, H. (2001) Beat Streets in the Global Hood: Connective Marginalities of the Hip Hop Globe, Journal of American and Comparative Cultures 24 (1-2), Bowling Green, OH: American Culture Association, Bowling Green State University, p. 172. 
У академском приступу савременој популарној култури у Србији, на појаву дизелаша и турбо-фолка почетком 90-их се обично гледа као на државни пројекат спроведен ради слабљења постојећих урбаних култура. Турбо-фолк се, такође, обично разматра у вези са национализмом и ауторитарном политиком. ${ }^{3}$ Такво резоновање је у великој мери одраз доминантног дискурса у Србији који има тенденцију да кривицу за нарастајућу неједнакост, стопу криминала, корупцију и остале друштвене проблеме који прате транзицију у капитализам, свали на плећа омладине из нижих слојева која тежи промени своје друштвене позиције не бирајући средства. Током 90-их хип-хоп заједницу у Србији је чинила, углавном, омладина средње класе која је прихватала доминантан, осуђујући морални назор према младима из нижих слојева и њиховим културним праксама. Отварање локалне хип-хоп сцене према другим поткултурама младих, а нарочито према дизелашима, било је, због тога, дуготрајан процес пун напетости и контроверзе.

У овом поглављу се одбацује идеја да су турбо-фолк и дизелашка култура инструментализовани друштвени феномени са утврђеним друштвеним и политичким циљевима дизајнирани од стране власти. ${ }^{4}$ Уместо тога, дизелаши се третирају као аутохтони урбани омладински покрет обликован друштвеном стварношћу мафијашког капитализма у Србији. Од свих горе наведених фаза развоја хип-хопа у Србији, управо је отворена комуникација са дизел етосом дала одлучујући допринос у преображају хип-хопа у широко прихваћену културу међу младима. Безбрижни став и народски музички избори дизел покрета помогли су да се хип-хоп у Србији поново повеже са својим заборављеним коренима везаним за журке и њихову друштвено мешовиту публику из раних диско дана. Између осталог, то ново, инклузивније усмерење хип-хоп заједнице у Србији огледа се и у делимичном препознавању и прихватању урбане ромске омладине као есенцијалне у обликовању локалне уличне културе а, самим тим, и хип-хопа. ${ }^{5}$

3 Gordy, E. (1999) The Culture of Power in Serbia: Nationalism and the Destruction of Alternatives, Pennsylvania: Penn State University Press, p. 19.

4 Видети: Dimitrijević, В. Globalni turbo-folk, 20. jun 2002., 15. mart 2019., http://www.nin.co.rs/2002-06/20/23770.html; Đurković, M. (2002) Diktatura, nacija, globalizacija, Beograd: Institut za evropske studije; Đurković, M. (2004) Ideološki i politički sukobi oko popularne muzike u Srbiji, Filozofija i društvo 25, Beograd: Institut za filozofiju i društvenu teoriju, Univerzitet u Beogradu, str. 271-284.

5 Matić, Đ. i Đogani, H. Leksikon YU mitologije, priredili Andrić, I. i dr. (2005), Beograd: Rende, str. 117-122. 


\section{Ђускај, Һускај, Һускај...}

Као резултат политике отворене културне размене са Западом, рани производи хип-хоп културе дошли су до Социјалистичке Федеративне Републике Југославије у првој половини 80-их, у исто време када пристижу и у Западну Европу. У престоничком Београду хип-хоп је нашао своје прве следбенике међу диско/фанк плесачима, диск џокејима и заљубљеницима. Бобан Петровић - један од најпопуларнијих, ако не и најпопуларнији диск џокеј и организатор забава у Београду, Србији и Југославији - објавио је 1981. суштински диско-фанк албум назван $Z$ ur. ${ }^{6}$ Сам Петровић је занимљива личност која је успевала да испуни клубове публиком разноврсних животних стилова из различитих друштвених слојева - познатим личностима, синовима и кћеркама бирократа Комунистичке партије, али и криминалцима, ентузијастичним диско плесачима и омладином радничке класе која је трагала за добрим проводом. ${ }^{\top}$ Симболично, може се тврдити да је нумера „Ђускај” са албума Жур послужила као манифест прве хип-хоп генерације социјалистичке Југославије. ${ }^{8}$ Иако Петровић у њој пева, његове риме сугеришу почетак нечег новог што се јасно разликује од рокенрола - музике која је до тог тренутка већ била прихваћена од стране југос.ловенских комунистичких власти и промовисана као пожељна култура урбане омладине. ${ }^{9}$ Петровић стаје у одбрану музике за журку и фанки (енг. funky) духа од свих рок критичара који су умањивали њихов значај, саопштавајући слушаоцу да музика не мора да носи „поруку и савет” (јер људи могу све да схвате сами, користећи сопствене менталне капацитете), већ да, једноставно, позива на плес. Он заокружује нумеру у истинском хип-хоп „представљачком” (енг. represent) стилу, тврдећи да су лични имиџ и текст песме

6 Petrović, B. (1981) Duskaj, na Žur [LP], Ljubljana: ZKP RTVL.

7 Musić, G. i Vukčević, P. Đogani šampion (istorija BEEGEE FONKa) - audio intervju sa Hamitom Đogajem Đoganijem, 31. januar 2009., 15. mart 2019., https://soundcloud.com/djapee/djole-shampion

8 Petrović, В. нав. дело.

9 Званичници КПЈ су средином 1960-их прихватили рокенрол као легитимну омладинску културу која има потенцијала да одрази социјалистичке вредности. Од тада се рок музика навелико емитује преко радио станица и постаје интегрални део омладинских манифестација које уживају подршку државе. Извођачи који су били вољни да у своје песме интегришу званичне државне симболе и револуционарне поруке, били су нарочито фаворизовани од стране власти; Видети: Đurković, М (2004) нав. дело, стр. 276-278 и: Vučetić, R. (2012) Koka-kola socijalizam: Amerikanizacija popularne kulture šezdesetih godina XX veka, Beograd: Službeni glasnik. 
главна ствар и сугеришући свим „музикантима” да рецитују своје текстове, јер „то је прави дар”. ${ }^{10}$

Пратећи Бобана Петровића, многи нови и перспективни уметници, наклоњени традицији фанк музике, почели су да уносе елементе хип-хопа у свој рад. Београдски новоталасни бенд $D u D u A$ објавио је 1983. године нумеру „Нор Ap Du Ap", у којој се појављују реп строфе, вероватно по први пут на било којем од јужнословенских језика. ${ }^{11}$ Тим електро-поп продуцената из Београда, Data, објавио је 1984. електро-фанк (енг. Electro-Funk) мини албум Degout под псеудонимом The Master Scratch Band, са нумером „Break War" као насловном. ${ }^{12}$ У тој песми, спикерка објављује: „улице су преплављене грамофонима и касетофонима" и „наш репортер је у болници, али је успео да пошаље извештај који гласи: Break War started!" ${ }^{13}$ Исте године је књига Brejkdensing Кертиса Марлоуа (Curtis Marlow) преведена на српскохрватски и објављена у Београду. ${ }^{14}$ У истом периоду су државне издавачке куће почеле да објављују бројне хипхоп, електро-фанк и диско-реп компилације и синглове на основу лиценци добијених од издавачких кућа из САД и Велике Британије као што су Sugar Hill Records, CBS, Charisma итд. Тако је до средине 80-их брејкденс достигао ниво „помаме” међу југословенским школарцима, који су опонашали плесне покрете и модне стилове виђене у медијима.

Разнородни аспекти ове нове урбане поткултуре неједнако су се, и на специфичне начине, ширили међу омладином различитих друштвених и етничких залеђа. Прве плоче са утицајима хип-хопа стварали су и уживали махом млади из више средње класе који су били у току са најновијим музичким трендовима. ${ }^{15}$ Након јаког утицаја панк покрета,

\section{Petrović, В. нав. дело.}

11 Du Du, A. (1983) Hop Ap Du Ap, na Primitivni ples [LP], Beograd: PGP RTB.

12 The Master Scratch Band (1984) Break War, na Degout [LP], Zagreb: Jugoton.

13 Ието.

14 Marlow, C. (1984) Brejkdensing (preveo Branko Gavrić), Beograd: Nezavisno izdanje Branka Gavrića.

15 Југословенска верзија „тржишног социјализма” охрабривала је друштвену неједнакост у већој мери него што је то био случај у друштвима Источног блока. Урбану средњу класу су чинили „бели оковратници” из успешнијих предузећа или државне администрације. Најповлашћенија омладина је потицала из породица партијских бирократа са виших позиција и руководилаца друштвених предузећа. На другом крају друштвене лествице, у урбаним срединама, била је позиционирана радничка класа „плавих оковратника" која је обично одржавала везе са унутрашњошћу, радницима досељеницима и ромском популацијом. За боље разумева- 
уметнички разнородна и авангардна новоталасна и постпанк сцена је процветала у југословенским урбаним срединама током 80-их. Уметници који су били најотворенији за нове утицаје почели су да уносе реповање и елементе хип-хопа у свој звук. ${ }^{16}$ Упркос негативним реакцијама колега уметника и конзервативних музичких новинара који су одрастали уз рокенрол гитаре, разни појединци са новоталасне/пост-панк сцене почели су да развијају интересовање за најновије трендове у „црној музици”. ${ }^{17}$ Један од најхаризматичнијих музичара који је потекао из овог миљеа - Душан Којић Која, лидер култне групе Дисуиплина кичме - почео је да кроз интервјуе, гостовања на радио станицама и као диск џокеј у алтернативним клубовима, промовише реп групе које су почеле да се појављују у другој половини 80-их попут групе Public Enemy. ${ }^{18}$

Алтернативна рок публика је прихватила реп музику са панк етосом. Реп је виђен као бунтовничка музика тешких бубњева, гитарских семплова (енг. sample) и јасне друштвене поруке. На другој страни, традиција хип-хоп културе везана за плес и журке наставила је да живи међу клинцима из нижих друштвених слојева. Многи од тих младих нису имали ранијих додира са рок музиком па су нове стилове својих вршњака из САД усвајали често их немарно мешајући са осталим утицајима западњачке популарне културе и локалним традицијама. Брејкденс је постао најзаступљенији елемент хип-хопа на улицама и у крајевима насељеним

ње друштвене диференцијације у СФРЈ. Видети: Archer, R. et al. (eds.) (2016) Social Inequalities and Discontent in Yugoslav Socialism, Farnham: Ashgate.

16 Видети нпр: Disciplina Kiěme (1987) Dečija pesma [LP], Beograd: PGP RTB, и Rambo Amadeus. (1989) Hoćemo gusle! [LP], Beograd: PGP RTB.

17 Најучесталија негативна критика реп музике је била да она и није музика пошто нема ,живих" инструмената. Реповање - или „рецитовање”, како су га рок критичари називали - такође је посматрано са висине и проглашавано превише једноставним и инфериорним у односу на певање.

18 Рок музичари који нису а приори одбацивали хип-хоп, одавали су признање само његовим рокенрол или фанк елементима који су звучали мање или више „тврдо”. Интервју Душана Којића Које за часопие Ritam открива ове ставове. У њему Која исказује отворени презир у односу на звук који су гајили Grand Master Flash и Afrika Bambaataa јер је „превише диско" и одаје признање само звуку групе Public Enemy, иако наглашава да нема ничег нарочито новог у вези са њиховом музиком јер „све je тo Wattstax"; Čikara, A et al. (1989) Betmen, Fantom, Mandrak... Koja! (Po drugi put) - intervju sa Dušanom Kojićem Kojom, Ritam, Vol. I, br. 5 , str. 20. Wattstax је назив добротворног концерта, као и документарног филма и аудио снимка истог којег је у лосанђелеском, претежно афроамеричком крају Вотс (енг. Watts) 1972. године реализовала водећа америчка соул издавачка куһа Stax - прим. прев. 
радничком класом. Ромска деца су као друштвено маргинализована, дискриминисана од стране образовног система и говорећи српскохрватски углавном као други језик, била нарочито привучена могућношћу личног доказивања кроз приказ физичке спремности и виртуозности. ${ }^{19}$ Као и кунг фу филмови и овај увозни културни производ у којем главни ликови нису били белци био је изузетно привлачан за ромску омладину. ${ }^{20}$ До краја 80 -их, хип-хоп је ушао на шире музичко тржиште, захваљујући успеху неких underground уметника који су експериментисали са реп музиком, као и са познатим поп музичарима који су, са намером да освеже сопствени имиџ, позајмљивали реп исечке, хип-хоп одевање, или тачке уличног плеса. ${ }^{21}$ Раних 90-их, чак су и фолк певачи почели да користе елементе хип-хопа у својим наступима. ${ }^{22}$ Овај тренд је само повећао видљивост хип-хоп културе за ширу публику и омладину радничке класе.

\section{Репенрол (Rap'n'Roll)}

Како су се 80 -е ближиле свом крају, рани дух мира, заједништва и љубави кроз забаву, промовисан од стране дискофанк диск џокеја попут Бобана Петровића, скоро да је нестао. Хип-хоп је проширио свој утицај далеко ван клубова у којима се пуштала плесна музика, али и даље није било кохерентног покрета младих способног да културу у целости отелотвори. На једној страни, хип-хоп су однеговали авангардни уметници пост-панк генерације који су позајмљивали одређене елементе реп музике за стварање сопственог звука, док је на другој страни један шири слој омладине, захваљујући популарним медијима, добијао само одблеске хип-хоп културе и моде. Тек је раних 90-их - са ширењем сателитске телевизије, музичких спотова, пиратских касета и, оно што је најважније, са појавом одређеног броја локалних

\footnotetext{
19 Matić, Đ. нав. дело.
}

20 Musić, G. i Vukčević, Р. нав. дело. Постоји и значајна историјска епизода са краја 1960-их када је бенд Eлипсе по први пут свирао соул и фанк музику у Београду а већину публике су чинили Роми. Према сведочанству Зорана Симјановића - лидера Елипси и најславнијег аутора филмске музике у Србији - атмосфера коју су Роми створили уз соул и фанк музику коју су Eлипсе свирале на својим наступима била је као у њујоршком Харлему. (Vukčević, P. Sa ove strane soula - intervju sa Zoranom Simjanovićem, 14. jun 2010., 15. mart 2019., http://www.popboks.com/article/8105)

21 Hпр. Balašević, Đ. (1989) Sugar Rap (Proces diferencijacije u Kombinatu za proizvodnju i preradu šećerne repe), na Tri posleratna druga [LP], Zagreb: Jugoton.

22 Hпр. Babić Sneki, S. (1991) Sneki Rep, na Hopa-Cupa [LP], Beograd: PGP RTB, и: Dabetić, Annči A. (1992) Noć ludila, na Anđeo za umornu dušu [LP], Beograd: PGP RTB. 
уметника који су потпуно ушли у културу - хип-хоп почео да постоји као независна, интегрална омладинска поткултура.

У другој половини 80-их плоче групе Public Enemy наилазиле су на добродошлицу и биле промовисане од стране одређеног броја рок музичких критичара, док су југословенске издавачке куће објављивале неке од најпознатијих наслова из каталога издавачке куће Def Jam - Beastie Boys, Run DMC, $L L C o o l J$ итд. Ови извођачи су привукли онај слој омладине који је био наклоњен електричним гитарама и сировим звуковима ритам машина. ${ }^{23}$ До почетка 90-их Србија је сведочила рађању нечега што се може назвати првом београдском/српском демо реп сценом. Бендови као што су Бадвајзер (Budweiser), Ghetto Blaster, Без каyunje, Green Kool Posse, Robin Hood и Who is the Best? су сви правили реп музику у класичном стилу издавачке куће Def Jam и Рика Рубина (Rick Rubin), стављајући нагласак на текстове који садрже тврдокорно локално/екипно представљање, пластичне описе свакодневног живота у граду и друштвено-политичке коментаре.

Овај окрет ка „белачкијем” звуку и „тврђим” текстовима одбио је део хип-хоп публике којег је више привлачио део културе везан за журке и плес. Како Матић пластично описује у свом огледу о чувеном плесачу Ђоганију као југословенском урбаном миту:

„Наши суграђани, они с руба, шљакери, пролетаријат, а поготово његов 'етнички' руб, Роми и Албанци - наши 'Цигани и Шипци', како смо им 'тепали' - нису се могли наћи у рокенролу, у проблемима што је постављао, у таквој стилизацији. То их се није тицало уопће, превише 'бјелачки' и middle-class. Требао им је властити звук, а кад су га добили, добили су га with a vengeance. Са ширењем диско-клубова, та сцена је добила и своје властите вриједности, своје xepoje. ${ }^{24}$

Хип-хоп клинци који су били заинтересовани за журку и плес су на прелазу из 80-их у 90-е прешли на звук група које су гајиле парти хип-хоп (енг. Party Hip-Нop) и јуроденс (Technotronic, Snap!, Mantronix, Bomb the Bass) или на mainstream извођаче из САД (MC Hammer). Почели су да опонашају плес и музичке стилове горе наведених извођача и поставили темељ за своју сопствену локалну сцену. Упркос

23 Def Jam звук је и био пројектован као ултимативни интеграционистички прелаз између „беле” и „црне” музике; Видети; Chang, J. (2005) Can t Stop Won't Stop: A History of the Hip-Hop Generation, New York: St. Martin's Press, pp. 244-246.

24 Matić, Đ. нав. дело, стр. 120. 
унутрашњим разликама - превасходно између клинаца које је занимао плес уз нумере за журку и репенрол клинаца које је више привлачило реповање тврдих рима преко битова на прелазу између репа и рокенрола - и иако је била релативно малобројна, ова генерација која је сазревала крајем 80-их је, посматрана као целина, прва генерација чији су припадници почели да доживљавају хип-хоп као заокружену, вишестрану урбану културу и животни стил.

„24 с̌аsa”, нумера Бадвајзера, најпопуларнијег репенрол бенда из овог периода, која је снимљена 1988, садржи вероватно прву забележену поетску (ауто)референцу на „репера" (енг. rapper) као на поткултурни идентитет у Београду и Србији:

\section{Ланац око врата, прстен на руку}

Репери се увек најбоље обуку

Навуци фармерке, обуци Адидас

Нико се не облачи боље од нас. ${ }^{25}$

Овај текст показује јасно препознавање поткултурног модностилског идентитета хип-хопа, које је исказано кроз борбено-представљачке (енг. battle/represent) риме. У истој песми, у којој се осликава обичан дан у животу младих београдских репера, Бадвајзери - који су сами свој стил музике назвали „репенрол” - исказују уважавање према рок музици, говорећи како је свирају на својим пробама; али је јасно да је реп њихов први музички и поткултурни избор. Њихов $M C$ репује следеће риме:

На пробу сам стигао тачно на време

Моји су свирку почели без мене

Свирали су рок, бучно и гласно

Рекао сам: „Доста! Је ли јасно?!”

Почели смо реп уз ритам јак

и свирали смо дуго док није пао мрак. ${ }^{26}$

Мотив који се понавља у овим раним објавама независности реп музике је да реп треба да буде препознат као издвојена локална поткултура урбане омладине - различита, на првом месту, од рокенрола уопште односно, конкретније, од панк рока. Вероватно најпрецизније и најуравнотеженије

25 Badvajzer (1987) 24 časa [Demo], 14. oktobar 2017., 15. mart 2019., https:// www.youtube.com/watch? $\mathrm{v}=\mathrm{rgIAO} 4 \mathrm{ilKkY}$

26 Исто. 
представљање односа прве демо-реп сцене на улогу хип-хоп поткултуре у развоју и рокенрола, као највидљивије локалне културе урбане омладине, дао је $M C$ Best, члан групе Who Is The Best? у њиховој песми из 1990. која носи назив „Rap is My Life":

Hit the road, rap! само кажу

и виде га као музичку бламажу

Ја сам рокер, али волим реп

За мене је он маштовит и леп. ${ }^{27}$

Упркос њиховом снажном осећају припадности хип-хоп култури, покушаји наведених уметника да се дистанцирају од рок миљеа откривају колико су они, заправо, у сваком погледу још увек били близу својим гитарским коренима. Било како било, до средине 90-их реп сцена Србије успела је да се рашири у већем кругу урбане омладине, установивши се као јасно издвојени правац међу урбаним поткултурама. Овај развој је убрзан нарастајућим утицајем америчког генгста peпа (eng. Gangsta Rap) ca Западне обале, поджанра који чак ни најдобронамернији рок критичари нису били спремни да прихвате. ${ }^{28}$ Нови гангстерски звук који се ослањао више на фанк наслеђе него на тешке битове и семплове гитара, као и на теме везане за улицу, дефинитивно су прекинули везе између локалне реп сцене и алтернативних музичких кругова који су се развили из рок наслеђа.

\section{(Пре)носиочи поруке Гета}

Недељна радио емисија под називом Гето, која је постала главни извор ширења радова нових реп извођача из САД, одиграла је кључну улогу у овом обрту. Са ауторитативним водитељима, листама иностраних синглова подржаним благовременим извештајима члана екипе Гета који је у то време био на школовању у САД, локалном демо листом и редовним живим укључењима слушалаца у програм у разговорима који су покривали широк обим тема везаних за музику и живот у великом граду, емисија се врло брзо установила као камен темељац београдске реп сцене па чак и успела да освоји титулу најслушаније емисије усмереног типа у целој земљи.

27 Who Is The Best feat. MC Best (1990) Rap Is My Life [Demo], na Soul Food Music [CD] (2005), Beograd: City Records.

28 Видети: Ambrozić, D. (1994) Crna kiša će pasti, Ritam, Vol. V, br. 4, Beograd: Izdavačka zadruga „Ritam”, str. 48-49, - прим. прев. 
Гето није просто одражавао главне трендове из САД, већ је уобличавао специфични локални укус. Током времена, емисија се развила у смеру промовисања мрачнијих генгста репера, који су гајили „опасан” звук - нпр. MC Eiht, Spice 1 и Scarface. Thug Life - Volume 1 - албум који је Тупак Шакур (Tupac Shakur) направио са својом екипом - задобио је култни статус међу локалним љубитељима репа. ${ }^{29}$ Шакурова директност и сирова, емотивна интерпретација, приближили су инострани реп многим младима који су имали ограничено знање енглеског језика. Касете са песмама снимљеним са радија, видео траке са реп спотовима са MTV, хип-хоп филмови и, повремено, примерци часописа The Source, Hip Hop Connection и сл., кружили су од руке до руке. До 1995. је џи-фанк звук постао стандард на локалној сцени, а извођачи као што cy Rhythm Attack, Гpy, CYA, Plan B, 187 и други приближили су тематику српског репа улицама, покушавајући да пронађу локалне пандане гангстерским темама из америчког репа.

Па ипак, хип-хоп израз и даље није био у стању да ухвати сирови доживљај локалних крајева. Репери су често користили неуправни говор, приповедали у трећем лицу, избегавали хвалисање и ретко помињали своја имена и специфичне локалне ознаке у римама, а песме су садржале морално дистанцирање од контроверзнијих тема. Упркос томе што су били опседнути сировим извештајима са градских улица, текстови и МС представљање џи-фанк генерације српског репа били су - у стриктном тврдокорном реп смислу МС вештине - корак уназад у односу на репенрол генерацију. Српске реп песме су најчешће звучале генерички, скоро као директни преводи америчких песама. Често су успевале да понуде информативне извештаје о уличној култури, али ретко истинске увиде у локални миље радничке класе и његово разумевање друштвене стварности.

Илустративан пример недостатка локалности у песмама џи-фанк генерације јесте први сингл групе 187 под називом „Тамна страна”. ${ }^{30}$ Из разговора са Предрагом Радисављевићем, бившим чланом групе, сазнали смо да је у првој верзији песме почетак његове строфе „Возимо низ улицу мртви од коке..." садржао конкретну локалну референцу на Пожешку (београдску улицу). Радисављевић и чланови његове групе су избацили име улице из текста песме јер су веровали да ће

29 Thug Life (1994) Volume 1 [CD], Los Angeles, CA: Interscope Records.

30187 (1995) Tamna strana, na Tamna strana [CD] (1997), Beograd: CentroScena/PGP RTS. 
се више људи пронаћи у римама ако не буду толико отворено локалне. ${ }^{31}$

Кроз џи-фанк године, идеја да реп музика има обавезу да се политички ангажује остала је присутна. Репенрол генерација уметника, која је снимала крајем 80-их и почетком 90-их, била је прва која је покренула тренд дубоких друштвених коментара из перспективе омладине радничке и ниже средње класе. Група Бадвајзер је то рекла директно:

Ми нисмо поп група која се у парама купа.

Са улице смо стигли и на врх се дигли. ${ }^{32}$

У наставку песме се повлачи линија разграничења између чланова групе и клинаца из богатих породица које живе у престижном београдском резиденцијалном насељу Дедиње:

Кафићи су скупи, потребни су новци.

Градом сада владају са Дедиња момци. ${ }^{33}$

Песма „Драма”, са првог званично објављеног српског реп албума Миленијум после - Мистерија I београдске реп групе Тапири, вероватно је најпроницљивији друштвено-политички коментар у српском репу с почетка 90-их. ${ }^{34}$ „Драма” хвата искуство 1993. године - најтрауматичније године у новијој историји Србије - током које су марширајућа инфлација, рат у бившој Југославији и криминализација друштва изазвали друштвену пропаст без преседана. Тапири су читав албум снимили током 1993., а исте године га је објавила државна издавачка кућа ПГП РТС. ${ }^{35}$ У овој нумери Милан Бојанић вођа и главни текстописац групе - почиње римама у којима говори о томе како чланове групе пријатељи наговарају да почну да праве музику за девојке. Бенд оставља отвореном

31 Вукчевић, П. Лични разговор са Предрагом Радисављевићем, 25. фебруap 2013.

32 Budweiser (1989) Čuješ li buku [Demo], na Omladina '9O [LP] (1990), Novi Sad: "M" Produkcija Radio Novog Sada.

33 Ието.

34 Tapiri (1993) Drama, na Milenijum posle - Misterija I [LP], Beograd: PGP RTS.

35 Чињеница да је државна издавачка кућа објавила албум Тапира који садржи нумеру као што је ,Драма" - нумеру која носи оштру критику режима Слободана Милошевића - служи као јак аргумент теоретичарима који одбацују тезу да је држава спроводила озбиљну културну политику у Србији током 90-их и да је, последично, турбо-фолк био пројекат власти. Она служи као аргумент за супротстављено становиште које тврди да је културна политика вођена у laissez faire маниру, односно препуштена динамици слободног тржишта. 
могућност да прихвати тај савет, али „за годину-две”зб, зато што је ситуација 1993. превише ургентна и чланови бенда морају да римују о њој. ${ }^{37}$ Као изазиваче рата и најодговорније за кризу у бившој Југославији ${ }^{38}$, бенд означава бирократе владајуће партије Србије - нарочито оне са Дедиња, београдског резиденцијалног насеља припадника више класе - као и оне из Хрватске; али успева и да ослика ситуацију из перспективе просечног градског клинца, римујући о шокантно високим ценама и немогућности доласка до патика и парфема, док су ,јакне (и) панталоне - све из каменог доба". ${ }^{39}$ Остатак албума такође садржи неколико рима које осликавају друштвену стварност Београда и Србије 1993., међутим, највећи део текстова је усмерен на паралелну традицију музике за журку и бави се шаљивим причама и стриктно МС „представљачким" римама. ${ }^{40}$

Прелаз на гангстерске теме и звук Западне обале, као што видимо, није довео до потпуног укидања обавезе на коментарисање друштвених појава, нити је раширио став да „праве црње не јебу живу силу"41, који је уобличен у поетским хвалисањима нових џи-фанк звезда у САД. За другу

36 Ове риме су се показале пророчким јер су Тапири заиста ушли у mainstream јуроденс музику 1995. године када су променили име у Tan 011 и почели да сарађују са две од најзапаженијих певачица у Србији 90их Иваном Павловић-Петерс и Горданом Гоцом Тржан. Касније су постали најуспешнији бенд те деценије у Србији.

37 Tapiri, нав. дело.

38 Милан Бојанић представља слично становиште у демо песми “Тime's Up," коју је 1994. написао за младу реп групу Belgrade Posse; Belgrade Posse (1994) Time's Up [Demo], 27. januar 2009., 15. mart 2019., https:// www.youtube.com/watch?v=B7SSOfe5Pvw)

39 Tapiri, нав. дело.

40 Морамо истаћи екипну џи-фанк песму „Сутра је нови дан” из 1994 године - нумеру са деби албума Само у сну којег је објавио Funky $G$, Ђоганијев млађи брат. (Funky $G$ he, у наставку каријере, своје уметничко име користити као име своје групе - прим. прев.) Песму је написао Милан Бојаниһ из Тапира, а снимили су је сreme de la creme извођачи српске јуроденс сцене 1990-их - Funky G, Tanupu и Duck. У тој нумери, извођачи који ће касније створити мноштво јуроденс хитова које је дизел публика обожавала, представљају свој безбрижни став наклоности журкама утврђујући истовремено свој урбани идентитет. Funky G одаје признање и саглапава се са музичким изборима својих слушалаца који наводно укључују рокенрол, реп, фанки и поп музику, док Duck одбацује фолк музику и захтева од слушалаца да „пљују народњаке” и да их презиру јер фолк музичари „село доносе у град"; Fanky, G. (1994) Sutra je novi dan, na Samo u snu [Cass], Beograd: MAT/Zmex.

41 У оригиналу "real niggaz dont give a fuck" као преовлађујући став репера који су представљали генгста реп сцену америчке Западне обале. Видиети: нпр. Dogg, Р. (1993) Niggas Don't Give a Fuck, in: Poetic Justice (Music From the Motion Picture) [CD], Los Angeles, CA: Epic Soundtraxприм. прев. 
генерацију реп група у Србији политички активизам остао је неопходан, ако не и суштински елемент хип-хоп културе. Ширење реп музике у Србији се поклопило са распадом земље, грађанским ратом, међународним економским санкцијама, нарастајућим сиромаштвом, криминализацијом и почетком транзиције из југословенског модела самоуправног социјализма у капитализам. Читаву последњу деценију двадесетог века обележила је интензивна политичка борба између ауторитарног режима оличеног у Слободану Милошевићу и опозиционих снага, која се често изливала на улице у облику митинга, протестних шетњи и сукоба са полицијом.

У оваквим околностима је, може се рећи, било неизбежно да локални репери почну да идентификују своју друштвену позицију са оном коју је имала афроамеричка омладина. Глас који репује у почетној шпици радио емисије Гето је објавио:

На нас не можеш да ставиш вето.

Разне игре - не помаже све то.

Криминал и глад, успон и пад,

јер ја сам ратник, а ово је гето.

Јасна је била намера да се повуче паралела између изоловане Србије 90-их погођене сиромаштвом и социјално угрожених урбаних језгара у САД, али је остало отворено питање где повући класне и етничке линије разграничења које су тако јасно исцртане у САД. Ко је био локални еквивалент „младом црном мушкарцу” о којем су реповали Chuck $D$ и Ice Cube? За шта реп заједница треба да се залаже и против кога треба да се бори?

Иако је још 1992. Хуса - Ром, лидер популарне српске реп, а касније јуроденс групе Beat Street - у демо песми „Beat Street" реповао лежерно на емисији националне телевизиje: „уз улични бит нигери су сви” ${ }^{2}$, пораст популарности џи-фанка је ипак праћен напорима да се осмисли место у хип-хоп култури и МС представљању за српске, односно неафроамеричке репере. Заједнички став реп сцене, окупљене око Гета, био је да реп групе треба да се боре против Милошевићевог режима заједно са рокенрол бендовима, да подржавају политичке снаге које се противе Милошевићу и да бране „урбани” дух од свих културних и политичких

42 Станојевић, М. (Редитељ), (1992) Таленmи 2000 - Beat Street [телевизијска емисија], први пут емитована 2. децембра 1992, СР Југославија: РТС. (2. децембар 1992., 15. март 2019., https://www.youtube. com $/$ watch?v=SFh6FbozZSw) 
напада, међу које су сврстани и репери усмерени на музику за журку, који су тежили комерцијалном успеху повезујући хип-хоп са јуроденсом и турбо-фолком.

$$
\text { У одбрану „урбаног” }
$$

Ране године транзиције ка економији заснованој на слободном тржишту донеле су драстично смањење животног стандарда велике већине становништва и богаћење малобројне елите. Режим је, у немогућности да одржи стара индустријска постројења и створи нова радна места, отворио врата неформалној економији као сигурносном вентилу на дну друштвене лествице. Многе породице из радничке класе су у урбаним срединама почеле да се укључују у црно тржиште, односно у трговину дефицитарном робом - превасходно горивом и цигаретама - која је кријумчарена под зидом економских санкција. То улично предузетништво „одоздо” које је узело маха, унело је нову друштвену динамику и подгрејало наде у брзо богаћење. Такође, упркос међународној изолацији, западњачки културни утицаји и потрошачка култура почели су да продиру у државу брзином која није виђена у време државног социјализма. Тржиште је врло брзо преплављено како оригиналном тако и фалсификованом брендираном робом, која је симболизовала добар живот и луксуз - спортским патикама, дизајнерским тренеркама, страним алкохолним пићима, електронском робом итд.

Без других начина да напредује на друштвеној лествици, омладина радничке класе је била нарочито склона усвајању тог новог етоса инстант конзумерства и „брзог” живота. Музичко залеђе ове друштвено-економске трансформације је постао турбо-фолк. У време социјализма, новокомпонована фолк музика проширила се у градовима заједно са радницима досељеницима, али су њени текстови и музика најчешће остајали верни традиционалним темама складног руралног живота. Раних 90-их, фолк музика је почела да прихвата утицаје америчког попа и јуроденса, али и грчких и турских поп фолк традиција. Тематика текстова се, такође, променила од чежње за идеализованом руралном прошлошћу у хедонистичко прихватање нових могућности које су се појавиле под окриљем мафијашког капитализма. Један од најпопуларнијих фолк уметника тог времена је био Џеј Рамадановски, београдски Ром, који је отворено говорио о својим искуствима са ситним криминалом и изградио свој имиџ као забављач са уличним педигреом. Џеј је увео узвике у стилу Џејмса Брауна (James Brown) у своје шаљиве риме, није се либио коришћења жаргонских израза и укључио је покрете уличних плесова у своје јавне наступе. 
Многи су појединци са уличне плесне сцене одиграли важне улоге у овом развоју. Један од најзначајнијих био је Хамит Ђогај-младићалбанско-ромског порекла из Миријева, односно Земуна, београдских радничких насеља. Ђогај - познат као Ђогани - почео је да се појављује на београдским диско/ фанк окупљањима још крајем 70-их, скупљао је професионално искуство као студијски плесач у емисији Show Fantastico на италијанској националној телевизији RAI Uno током 80-их, да би се почетком 90-их вратио у Србију где отвара школу за уличне плесове и наступа са својом групом Ђогани Фантастико као плесна пратња многим турбо-фолк звездама. Касније, током 90-их, Богани Фантастико почињу да објављују сопствене албуме и успевају да постигну неколико великих хитова - углавном јуроденс, али и њу-џек-свинг (енг. New Jack Swing) нумере са оријенталним/турбо-фолк призвуком. Уз то су и Ђоганијева млађа браћа и рођаци Funky G, Baki B3 и Sani Trik FX - направили каријере на српској јуроденс и поп музичкој сцени, поставши тако прве звезде ромског порекла - поред Џеја Рамадановског и Хусе из групе Beat Street - које су се редовно појављивале у главним телевизијским емисијама у Србији током 90их.

Прву половину 90-их је обележила неформална економија и организовани криминал. Локални криминалци су преузели контролу над насељима великих градова, представљајући се као борци против актуелних власти и заштитници сиромашних ${ }^{43}$ Млади људи - повезивани са поменутом новом врстом урбане музике, уличним мешетарењем, теретанама и боди билдингом, жестоким ставом, брзим аутомобилима и скупом спортском одећом ${ }^{44}$; и који су се угледали на младе гангстере, све популарније у српским урбаним срединама попут локалних „Робин Худова” - врло брзо су од стране локалних медија названи дизелашима. ${ }^{45}$ Дизел поткултура

43 За традицију друштвеног разбојништва на Балкану видети: Hobsbawm, E. (2000) Bandits, London: Weidenfeld \& Nicolson, pp. 77-91.

44 Неки од омиљених дизелашких брендова спортских патика били су Nike Air Max, Puma Disc и Reebok Pump који су продавани по ценама које су одговарале вредности 20-30 просечних плата у Србији у време када су се појавили средином 90-их. Била је уобичајена ствар да тинејџерима патике буду отете на улици, усред бела дана и углавном уз употребу физичког насиља

45 Име је настало од назива популарног џинс бренда тог времена - Дизел (Diesel). Филм Ране и документарац Buдимо се у читуљи бацили су више светла на микроконтекст у којем је настала дизел контракултура. Bjelogrlić, D. i dr. (Producenti) i Dragojević, S. (Reditelj) (1998) Rane [igrani film], SR Jugoslavija/Nemačka: Cobra Film Department/Pandora Filmproduktion; Baljak, J. (Reditelj) (1995) Vidimo se u čitulji [dokumentarni film], SR Jugoslavija: RTV B92. Видети такође и: Лекић, М. (Аутор) и Јанковић, И. (Редитељ) (1994) Welcome to Дизелдорф [документарни филм], 
је била локални друштвени феномен чије су вредности и естетика били блиски гангстерском ставу америчке омладине из угрожених урбаних језгара. Како Квин (Quinn) истиче у покушају објашњења афроамеричке џи-фанк генерације: „Гангстеров водећи етички принцип агресивног економског самоодређења је очигледно легитиман када се посматра као тактички одговор на непрекидно лишавање приступа ресурсима, правима и начинима отпора" ${ }^{46}$ Дизелаши су развијали тај гангстерски однос према животу у истом духу у којем су то њихови афроамерички вршњаци чинили на Западној обали, широм америчког Југа и на другим местима у то време. Ограничене могућности за напредовање у друштву су их гурале у идолизовање „прекомерног трошења и самоодређујуће пословне праксе,” водећи их до закључка да је „најбоља освета живети добро". ${ }^{47}$

Џи-фанк генерација српских репера је пазила да се не приближи дизелашима. Чланови бенда Ding Dong - реп групе из Ниша, трећег по величини града у Србији - на свом хит синглу из 1999, „һелав сам па шта”, репују о томе како не желе да буду упоређивани са дизелашима, иако фурају исту фризуру: „А ако ми кажеш да сам дизел./ ја ћу тебе као Мадону Шон Пен". ${ }^{48}$ Главна мета критика у реп песмама су остали корумпирани политичари и припадници виших класа, али су репери такође свој бес почели да усмеравају према онима који су били испод њих. Реп сцена је преузела активну улогу у таласу моралне индигнације у односу на дизел културу као и на припаднике других маргинализованих друштвених група који су покушавали да се уздигну на друштвеној лествици током тешких времена.

Главни проблеми у вези са дизелашком контракултуром су, из реперске перспективе, били следећи: 1) Генеричке и претерано поједностављене романтичне и веселе песме за журку, без икаквог друштвеног или политичког коментара; песме које су (репери - прим. прев.) доживљавали као покушај заглупљивања и скретања пажње публици са правих проблема и, самим тим, као помоћ режиму; 2) Чињеница да телевизијске и радио станице нису цензурисале наведене песме, док реп и рок песме јесу, и 3) Чињеница да су дизелаши

СР Југославија, 5. октобар 2014., 15. март 2019., https://www.youtube. com/watch?v=q7xucYJLEiw. - прим. прев.

46 Quinn, E. (2005) Nuthin' But a G Thang: The Culture and Commerce of Gangsta Rap, New York: Columbia University Press, p. 169.

47 Исто, стр. 170.

48 Ding Dong (1999) Ćelav sam pa šta?, na South Side [CD] (2000), Beograd: CentroScena. 
били веома агресивни и често иницирали физичке сугобе са другим поткултурним и контракултурним групама.

Реп група Magic People из Новог Сада - другог по величини града у Србији - отворено је представила жестоки дизелашки став у својој демо песми „Diesel People” из касних 90-их, римујући о регуларном вечерњем изласку у град и пребијању других, недизелашких екипа. ${ }^{49}$ Једно издање Ге$m a$ је, такође, добро одразило наведено расположење. Слушаоци су позвани да искажу став о друштвеним групама са којима имају највише проблема и да их прогласе недостојним живота у Београду. Љубитељи репа су углавном помињали турбо-фолк музику, дизелаше, ратне избеглице и Роме као главне проблеме у свом најближем окружењу.

Све ове друштвене групе су обично паковане заједно под називом „сељаци” - термином који се користи за вређање новопридошлих досељеника из унутрашњости, али и нижих слојева уопште, који се наводно опиру интеграцији и прихватању „градских” манира средње и више класе. $M C$ Best, оснивач Гema и вођа групе Who is the Best? - једне од ретких група из репенрол генерације, која је успела да се прилагоди новом џи-фанк звуку - написао је 1994. следеће стихове:

За глупе сељаке то је нешто пето

$(\ldots)$

Јер ово је мој град смрадови

Напоље олош и гадови

С оне стране Дрине у три материне $!^{50}$

Хип-хоп је, дакле, био љубоморно чуван и схватан од стране многих као ексклузивно право, резервисано за становнике урбаних насеља, који су довољно софистицирани да у потпуности разумеју и уважавају уметност. Овај антагонизам у односу на младе из радничке класе који су упражњавали хип-хоп културу на свој начин као и у односу на друге, аутентичније градске уличне поткултуре, био је рационализован на два нивоа: на првом нивоу, то је био аргумент „праве главе против лажних", који се често користи у хип-хоп заједници. Они који су плесали ${ }^{51}$, слушали комерцијалније

49 Magic People. (1998) Diesel People [Demo], 28. februar 2011., 15. mart 2019., https:/www.youtube.com/watch?v=RgamOKCb5po.

50 Who Is The Best?. (1992) WITB Strikes Again [Demo], na Welcome to Belgrade [CD] (1995), Beograd: ITMM.

51 љубитељи репа у Србији који су пропустили брејкденс епоху или пратеће плесне групе Златног доба репа и ушли у културу посредством умртвљених звукова генгста репа са Западне обале или тврдокорних 
реп извођаче или мешали хип-хоп са турбо-фолком, одбацивани су као „фејкери” који доприносе негативном имиџу репера у очима јавности и других, цењенијих поткултура младих (нпр. љубитељима „гранџа” (енг. Grunge) и алтернативног рока).

Испод површине је, међутим, било дубљих културних и политичких разлога. Хип-хоп је у Србији, пре свега, схваћен као „урбана” култура. У изворном америчком контексту појам „урбано” - у контрапозицији са средњекласним предграђима - јасно указује на угрожена постиндустријска градска језгра и њихове сиромашне становнике. У Србији, у којој урбанизација и досељавање из унутрашњости и даље трају, „урбано” представља културни капитал који се повезује са повлашћенијим друштвеним слојевима. У времену политичке и економске кризе, урбана средња класа која је настала у време социјализма, доживела је нову друштвену покретљивост као претњу, заузимајући одбрамбени став у односу на новоформирану класу имућних, али и у односу на ниже слојеве друштва који су покушавали да опстану укључивањем у неформалну економију.

Опозиција, која је имала своју базу у великим урбаним центрима и уживала подршку већине реп група, користила је дискурс оријентализма и капиталистичке модернизације да би критиковала владајућу клику окуп.љену око Слободана Милошевића. ${ }^{52}$ Тврдили су да је режим састављен од преосталих комуниста који су се, зарад останка на власти, ослањали на подршку радничке класе, сељака, пензионера и криминалаца. Из перспективе активиста опозиције, тај савез је уништавао урбану популацију и њену културу засновану на увезеним утицајима западњачке културе током претходних деценија. Систем је, наводно, упорно гурао друштво на исток, даље од модерне западњачке демократије и просперитета тржишне економије. Турбо-фолк је, на пример, углавном био критикован због преузимања оријенталних мелодија и спречавања развоја популарне музике у западњачком стилу. Дизелаши тако нису били опажани као жртве већ као повлашћеници Милошевићевог режима. Већини репера се више свиђало да играју улогу конзервативних чувара старих вредности и да се надају бољим данима, уместо да пригрле нову урбану стварност периферног капитализма.

реп извођача прве половине 90-их као што су Wu Tang Clan, плес никада нису доживљавали као део реп искуства. Мали број девојака је био присутан на реп концертима, а понашање публике је често подсећало на понашање публике на тврдокорним панк концертима са шуткама и уопштено напетом атмосфером.

52 Durković, М. (2004) нав. дело, стр. 271. 


\section{Ви сте мислили да смо се смирили?}

Након НАТО бомбардовања 1999. и свргавања Милошевића са власти 2000., српско друштво је у нови миленијум ушло са великим очекивањима. Стратегија економског и друштвеног развоја нове, отворено про-западњачке и неолибералне Владе била је заснована на финансијским кредитима и инвестицијама глобалних финансијских организација и мултинационалних корпорација, које је требало да подигну животни стандард и приближе Србију „нормалности” по мерилима друштава Западне Европе. Међутим, уверење и страх да 90-е нису нестале, проширили су се врло брзо међу становништвом. Економске потешкоће су се наставиле, а политичка сцена је остала контроверзна, са отвореним сукобима између главних политичких странака, државних безбедносних агенција и организованих криминалних група. Скандали у вези са сумњивим приватизацијама друштвених и државних предузећа од стране домаћих и иностраних купаца преплавили су медије.

Са добро етаблираном културом окупљања уз електронску музику и великим избором јефтиних наркотика на црном тржишту, млади су се, тражећи утеху, окренули радикалном хедонизму и ноћном животу који се брзо развијао. Није било више жаљења, присећања на боље дане, или илузија да ће све бити боље са будућим променама влада. Тај нови дух деморализације и немоћи је, парадоксално, отворио могућност хип-хоп заједници да поново размотри догађања у својој средини и да коначно у стварном животу српских улица препозна потенцијал за реперско надахнуће. Почетком 2000-их је, заједно са техноом, хип-хоп постао најраширенија култура младих у Србији. Поред реп сцене, и нове екипе би-бој (енг. BВоу) плесача и цртача графита почеле су да се формирају и јачају на нивоу целе државе. Журке са хип-хоп и ар-ен-би (енг. $R$ ' $n$ ' $B$ ) диск џокејима постале су популарне у београдском ноћном животу након 2002. године, стварајући опуштенији и отворенији простор који се ретко налазио у атмосфери чистунства и самодопадљивости реп сцене 90-их.

Нову хип-хоп естетику је најавила нумера под називом „Ко ће то да плати?" ${ }^{3}$ Песму је снимила група VIP, коју су чинили Бус (Juice) - репер који је активан још од 90-их ${ }^{54}-$ и

53 VIP. (2001) Ko će to da plati? [Demo], 10. maj 2011., 15. mart 2019., https:// www.youtube.com/watch? $\mathrm{v}=0$ XYZIBdJaH8.

54 byc jе 90-их био део групе Full Moon која је свој деби албум, испуњен тинејџерским интроспективним римама и бум беп (енг. Boom Bap) битовима, објавила 1998. 
два београдска емсија у налету, Икаи и Рексона (Rexхxоna). Иако су успели да сниме само једну песму пре него што су се разишли, та нумера је постала темељ тврдокорног уличног репа у Србији. Жестоке риме које су се кристализовале у рефрену, представљају вероватно најснажнији генерацијски крик у локалном репу који је ухватио стање духа већег дела урбане омладине у Србији почетком двадесет и првог века:

Десет година у беди, брате - ко ће то да плати?!

Десет година стрпљења, брате - ко ће то да плати?!

Скупа кола, црна кожа, клима - ко ће то да плати?!

Сваки дан да се има - ко ће то да плати?!

Наше поштовање кошта, брате - ко ће то да плати?!

Да се екипа скине с ћошка, брате - ко ће то да плати?!

Лепе рибе, нове ствари - ко ће то да плати?!

Путовања, ресторани - ко ће то да плати?! ${ }^{55}$

Тако страсно исказивање глади градских клинаца за материјалним богатством и њихова потреба да достигну друштвени статус, живо осликано коришћењем локалних симбола, није никада раније виђено у српском репу. Није било жалби на изгубљени урбани идентитет, представљања себе као жртве нити вађења на друге. Ђус је систематично, без резерви реповао у дизел духу, препознајући гомилање луксузне робе као једини начин да се освоји поштовање у друштву:

Хиљаде марака, треба ми нов пар ципела и патика.

Без кеша осећам се попут земљорадника.

Ja xoћy BMW 3 TDI, два-три Golfa, CRX Honda

и пун ноћни пазар Монда. ${ }^{56}$

Икаи је 2001. године снимио сличну химну под називом „Атлантида (Мало пара - пуно стида)”, у којој је први пут дизел поткултура отворено повезана са реп музиком:

У ова четири зида нисам навик'о да губим

Репер и дизелаш, брате - прави Србин!

Навик’о да љубим, волим да карам, 
ГОРАН МУСИЋ и ПРЕДРАГ ВУКЧЕВИЋ

Паре да стварам, мало да варам. ${ }^{57}$

Наредних година, Икаи је наставио да испоручује снажне риме које су прокламовале поглед на свет уличних клинаца/ дизелаша. У песми „Мој живот” на пример, Икац испоручује истинско дизелашко стање духа:

Почео да тренирам, дух ми је немиран.

Moje је у питању - начин често не бирам.

Знам да се изнервирам, знам да се побијем,

Решим овај живот сам да добијем. ${ }^{58}$

Па ипак, пуна локализација репа кроз његову везу у развоју са дизел контракултуром, морала је да сачека Бусову солистичку обраду теме.

byc је свој солистички деби албум Hiphopium објавио 2002. Као већ остварени цртач графита и $\mathrm{MC}^{59}$ - а опажен и као чувар „истинског хип-хоп духа”; нечег што већина српских хип-хоп глава не би ставила у исту реченицу са дизел контракултуром - $Б y c$ је успео да постигне велики успех са првим синглом са свог албума, песмом по имену „Кеш колица”. ${ }^{60}$ Песма је сместа постала класик мећу љубитељима репа, као и изван граница жанра, упркос - или захваљујући - чињеници да је била дубоко уроњена у дизелашки светоназор. Љубитељи репа који су посумњали да се нешто „чудно" дешава у песми, одлучили су да је схвате као саркастични осврт на тему младића који желе да муљају, а који обично долазе из дизел поткултуре и деле дизелашке манире и поглед на свет. Поред ове песме, албум је садржао и скеч са делом песме Мухарема Сербезовског, ромске легенде фолк музике. ${ }^{61}$ Опште одушевљење које је владало у вези са овим албумом као једном од првих објава нове генерације српског репа, а уз њега и Бусов статус „праве хип-хоп главе", заштитили су га од оптужби за продају дизел публици и зацементирали његов статус класика. ${ }^{62}$

57 VIP (2001) Atlantida (Malo para - puno stida), na TILT Volume 1, Beograd: Tilt.

58VIP (2002) Moj život, na Bassivity Mixtape - Prvi put [CD], Beograd: Bassivity Music.

59 Видети: Zupanc, G. (Rediteli) (1999) Pećina [dokumentarni film], SR Jugoslavija: Dunav film i Art TV, 22. септембар 2009., 15. март 2019., https:// www.youtube.com/watch?v=FegzK11Z6rY - прим. прев.

60 Juice (2002) Keš kolica. na Hiphopium [CD], Beograd: BK Sound.

61 Juice (2002) Zovi me (skit), na Hiphopium [CD], Beograd: BK Sound.

62 Важно је нагласити да прилагођавање дизелашкогстава није једини начин на који је хип-хоп локализован у поменутом временском периоду Одвојено од Ђусовое дијалога са омладинском дизел културом, јоп један 
Још један важан историјски моменат који се догодио на Ђусовом деби албуму је била његова обрада „Ђускај” Бобана Петровића. ${ }^{63}$ Необична вредност ове обраде се може разумети тек ако је контекстуализујемо супротстављајући је већини српских реп нумера с почетка XXI века, које су покушавале да опонашају њујоршке реп стилове из 90-их, као и увреженом мишљењу да су реп песме за журку, у најмању руку, исподпросечне у односу на сирове представљачке или политички ангажоване песме. Поред исцртавања директне везе корена репа у Србији са почетка 80-их и његових најновијих развоја неких двадесет година касније, Ђусова обрада „Ђускај” је најавила важан нови развој који ће постати очигледан на његовом другом албуму.

Ђус се вратио на сцену 2006. са својим другим албумом Брате минли. Први сингл, насловна нумера, погодила је жестоко реп сцену, моментално створивши контроверзу. $Б$ кус и његова екипа $93 F U$ појавили су се у споту за „Брате минли” са фризурама, тренеркама и Nike Air Max патикама популарним међу припадницима дизел поткултуре 90-их. У пратњи две полуголе го-го играчице, $Б у с$ је реповао следеће риме:

Ви сте мислили да смо се смирили?!

У ствари смо се узнемирили.

Мало сте рибе фурали, мало се ширили,

Мало се туђим перјем китили,

Док ми смо у крају и живимо реалност.

За ваше песмице ви тражите захвалност. ${ }^{64}$

значајан развој је дошао из 43-23 круга који су започели Ајс Нигрутин и Тимбе (познат и као Бдаm Irlymuм), оснивачи славне реп групе Bad Copy. Утемељен крајем 90-их, 43-23 круг уметника је нарастао у првој половини 2000-их и укључио уметнике међу којима су легендарни тврдокорни реп бенд Прти Бее Гее, први тврдокорни женски реп пројекат Бичарке на трави, мултиталентовани инструменталиста, freestyle и pariy $M C$ Wikluhsky и познати тврдокорни репери са препознатљивим стиловима - Бвана, Seven и $L u c a$ H8R. Њихово представљање и стил су, у неку руку, били опуштенији и неконфронтативнији у односу на став bycoвe 93FU екипе, са већим нагласком на различите хедонистичке аспекте свакодневног живота у крају. Презир према свему ппто није било underground или потпуно „Прљаво", понекад је чланове 43-23 круга водио у отворено изругивање ,дизелашким" материјалистичким претензијама њихових вршњака. Било како било, њихови забавни и ингениозни крајевски извештаји, као и аутентични сленг изрази које су сковали и популаризовали, помогли су им да постану једно од главних упоришта тврдокорног репа у Србији.

63 Juice (2002) Đuskaj, na Hiphopium [CD], Beograd: BK Sound.

64 Juice 93FU feat. 93FU. (2006) Brate minli, na Brate minli [CD], Beograd City Records. 
Било је јасно да се Бус бори против читаве реп сцене, оптужујући је да је мање „права” од дизелаша, ако је уопште права. Дизел идентитет који су он и његова екипа одабрали да представљају није, међутим, употребљен само због његове шокантности или борбене вредности. Током читавог албума јасно је показано да се концепт ослања на премису да реп треба да представља урбани живот локалним симболима, победничким тоном и са нивоа улице - или, прецизније, из перспективе клинаца из радничке и ниже средње класе као и то да су дизел поткултура и њен поглед на свет најадекватнији локални еквивалент уличне културе америчких угрожених урбаних језгара. ${ }^{65}$

У нумери која отвара албум - „Увертира лектира” - Бус даје савете својој генерацији да прекине са пуцњавама и коришћењем дрога, да почне да вежба, итд. - савете које би, углавном, одрасли дизелаш дао другом дизелашу ${ }^{66}$ Ова нумера одређује тон читавог албума - Бус је озбиљан када прича причу о Србији „од деведесет прве, друге, треће...” када „прича наопако креће". ${ }^{67}$ Он, међутим, на другој страни представља грубу стварност кроз горко-слатке шаљиве увиде, иронично саопштене анегдоте и епизоде које често звуче надреално, а током већег дела времена се на албуму одвија журка. ${ }^{68}$ И летимичан поглед на списак гостију на албуму и извођача који су семпловани - Тапири, Хуса из групе Beat Street, Иван Гавриловић, односно, „најбоље од најбољег” са српске јуроденс сцене и сцене репа за журку 90-их - показује као самоочигледно да је, како је Бус касније објаснио у једном интервјуу, његова намера била да освежи читаву реп

65 Још једна важна интертекстуална референца на песму „Драма" Тапира се налази у Брате минли када Ђус репује о потрази за новим патикама које се не могу наћи нигде у граду, нарочито не чувени Nike Air Max модели из 1990-их који су били статусни симбол дизелашке екипе.

66 Juice 93FU (2006) Uvertira lektira, na Brate minli [CD], Beograd: City Records.

67 Исто.

68 Сличан дуализам је дубоко укорењен у концепт $93 F U$ - назив $Б$ Бусове екипе. Број „,93" се односи на 1993. годину - годину потпуног краха система у Србији и Југославији са огромном инфлацијом, таласом криминала, несташицама хране итд. - док „FU” може бити тумачено као сленг израз који се користи да изрази узбуђење које изазива нешто лудачки добро и свеже (енг. fresh), али такође и као скраһеница од ,jебите се", (енг. Fuck $U$ ) што такође даје два могућа тумачења када се узме заједно са ,93”. Једно тумачење би било нешто попут „Ми смо 93, јебите се!“", а друго „Јебеш 1993. годину!" Све у свему, концепт покушава да обухвати бес према свима који су створили крах друштва везан симболички за 1993. годину и број „93" и, истовремено, победничку животну филозофију Бусове (и дизел) екипе, засновану на успеху у преживљавању најгорих могућих друштвених околности; Вукчевић, П. (20. децембар 2012) Лични разговор са Иваном Ивановићем Jиісеот, 
сцену Србије из средине 2000-их, да шокира и да оконча нагли пораст досадних и преозбиљних реп песама. ${ }^{69}$

Снажни и сложени поетски развоји на албуму Брате минли који реферишу на стварни живот српских клинаца са улице на свим замисливим нивоима, преплављени локалним референцама и подржани сировим, дигиталним битовима чији је аутор Салиер дел Флорес (Salier Del Flores), који су комбиновали утицаје џи-фанка и дрти-саут стилове (енг. Dirty South) са пар јуроденс и фолк додатака ту и тамо, учинили су овај албум регуларној реп публици јако тешким за праћење и прихватање. Узгред, аспект албума везан за журку и хедонизам није ограничен на позивање на 90-е и дизел контракултуру. Сам наслов албума и првог сингла - брате минли - заправо је поздрав београдских посетилаца журки, диско плесача и муљатора из 1970-их - људи из истог фанки миљеа из којег је Бобан Петровић кренуо да би створио свој прото-хип-хоп/диско-фанк звук Београда. Овај увид указује на потпуно нови симболички ниво Бусовог репа, отварајући простор за једну интерпретацију која Брате минли представља у виду покушаја успостављања неке врсте виртуелне фанки традиције београдске уличне културе кроз генерације. $^{70}$

Цена коју је Ђус платио за васкрсавање своје поетске личности у тако блиској размени са пролетерским културама био је презир од стране конзервативнијег језгра српске реп заједнице. На другој страни, његово храбро дело је помогло у стварању прекретнице у локалном реп изразу са дизел поткултуром која је постала интегрални део дискурса локалне реп сцене. Штавише, нова генерација младих који никада нису искусили турбулентне 90 -е, безрезервно су пригрлили стил са дизел шмеком. Чињеница да се хип-хоп у Србији коначно повезао са улицом потврђена је у зиму 2008. године, на београдским уличним протестима. Године 90-е су обележиле опозиционе демонстрације и масовне уличне шетње, организоване у знак подршке званичној политици режима

69 Vukčević, P. Rispekt za iskrene ortake - video intervju sa Ivanom Ivanovićem Juiceom, 23. decembar 2008., 15. mart 2019., http://www.popboks.com/ article/6980; читав наведени обрт у Ђусовом звуку је најављен његовим озлоглашеним гостовањем на хит песми групе Funky G из 2005. „У твојим колима", када је први пут у својој каријери разбеснео реп публику бацањем пмекерских рима преко оријенталног хип-хоп бита који су Funky G преузели из француског реп хита „Just Married” који потписују Relic и Amine; Relic feat. Amine (2004) Just Married [CD Single], Paris: Barclay.

70 Видети: Vukčević, P. Mlad (i zdrav) kao rap: I brate, brate, brate - jedna tradicija srpskog hip-hopa (2), 3. јануар 2009., 15. март 2019., http://www. popboks.com/article/7021 - прим. прев. 
Слободана Милошевића. Конзервативна Влада Србије је 2008. решила да још једном подигне грађане на ноге, у знак протеста против отцепљења Косова, јужне покрајине Србије, насељене већинским албанским становништвом. Влада је прогласила нерадан дан у државним школама, надајући се да ће привући омладину на националистички обојене протесте. Омладина је заиста изашла на улице, али су се многи од њих одвојили од главне колоне демонстраната и кренули да проваљују у спортске бутике и краду брендирану робу. Радња бренда Nike је била једна од главних мета у којој су млади грабили ретро Air Max моделе - моделе патике која је постала симбол дизел генерације раних 90-их.

Једна од најпопуларнијих српских реп група последње генерације - THC La Familija - 2009. је објавила хит нумеру под називом „Тренерка стил”, у којој је чујан утицај и улични кредибилитет дизел поткултуре:

Тренерка стил - носе је сви.

Улице прати дух деведесетих. ${ }^{71}$

Млада српска реп звезда по имену Марлон Брутал, који представља немилосрдне екипе фудбалских навијача из свог новобеоградског блока, развио је ову поенту речима:

И нисам раст'о с пичкицама, него с навијачима.

И нисам раст'о с реперима, него с дизелашима. ${ }^{72}$

Коначно, један од највећих хитова у држави 2010. године назван „Dizel Power” - нумера Бусовог пулена и тврдокорног репера који је себе назвао Dance Don Shwarz и, практично, прилагођавање јуроденс звука за 2009., направљено у сарадњи са Слађом Делибашић, бившом женом Хамита Ђогаја и бившом главном невачицом групе Богани Фантастико заокружио је све за генерације које долазе, стиховима:

Плејер је на мајку, стари догови у Најку ${ }^{73}$,

У звучнике ти стижем к'о да подиг'о сам хајку.

Цифре нек' се броје, великани нека стоје.

Сада склоните се сви када узимамо своје.

Само бизнис, ништа лизинг,

71 THCF. (2009) Trenerka stil, na Majmun idzuo [CD], Beograd: Tilt.

72 Marlon Brutal. (2009) HCZ KCZ [Demo], 6. septembar 2010., 15. mart 2019., https:/www.youtube.com/watch?v=WNIZ3Jhp_wQ

73 Фонетски транскрибован назив бренда Nike на српски језик - прим. прев. 
Само крупно, ништа ситниш,

Ми смо бахати у свему, брате, кад ћеш то да схватиш?

Ми смо dizel power - да ли можеш да нас пратиш? ${ }^{74}$

$$
\text { Закьучак }
$$

Током последње три деценије, вршњачке групе и појединци иницирани у хип-хоп културу у Србији били су под непрекидним притиском у погледу трагања за новом поткултуром, идентитетом и праксама које би биле више „праве” (што се односи на локалне друштвене феномене који одговарају онима који су описани у реп музици из САД). Хипхоп је тако био у могућности да се развије и дође до већег броја следбеника непрекидним мирењем увозних звукова и слика са стиловима, језицима и модама присутним на улицама градова Србије. Капацитет за филтрирање увежених стилова и њихову примену на домаће контексте је, у великој мери, зависио од друштвене позиције оних који их преносе. Захваљујући већој куповној моћи и познавању страних језика, појединци из виших класа су били у бољој позицији да усвоје и преведу хип-хоп као оскудно увозно културно добро. То су обично биле „реп главе” са развијеним осећајем за детаље и разумевањем хип-хопа као интегралне културне форме. На другој страни, за појединце из нижих слојева је било вероватније да ће примити само одређене елементе хип-хопа и то обично оне преношене од стране mainstream културе.

Хип-хоп су 80-их преузели и промовисали делови новоталасне/панк сцене привучени тешким битовима и гитарским семпловима са раних Def Jam снимака, као и субверзивним имиџом репа. Истовремено је култура ушла мећу народскију диско публику и раширила се међу омладином радничке класе у форми брејкденса. Ова дихотомија се наставила 90-их развојем затворене заједнице љубитеља репа који су инсистирали на уличним темама и друштвеним порукама на једној а, на другој страни, групама које су биле оријентисане на журке и плес и у блискијем контакту са локалним укусима (нпр. турбо-фолком) и поткултурама младих из радничке класе попут дизелаша. До краја 90-их је реп музика постала доступнија широј публици, а језгро реп сцене је успело да преведе и рашири стил у већим круговима младих. Било је право време за синтезу. У првим годинама новог века тај је културни трансфер из САД открио сличности са

74 Shwarz (2010) Dizel Power [Demo], 6. jul 2010., 15. mart 2019., https:// www.youtube. $\mathrm{com} /$ watch? $\mathrm{v}=\mathrm{gwG} 98 \mathrm{baHZ} 88$ 
аутентичнијим локалним трендовима и поткултурама младих из радничке класе, као што су хедонистичке традиције локалне клабинг (енг. clubbing) сцене, турбо-фолк и култура фудбалских навијача.

Веза између дизел и хип-хоп поткултура показала се као суштинска у овом процесу. Прилагођавање дизел ставова, симбола и језика је донело српском репу културни и класни кредибилитет и додало преко потребни локални шмек, а реп текстови су заузврат дали јавни глас маргинализованој дизел поткултури. По први пут од раних 90-их, омладина из нижих слојева која се упињала да задобије друштвени статус у источноевропском транзиционом капитализму, кроз легалне и илегалне шеме, била је представљена чињеничним описима без морализаторског призвука. Будући развој реп израза у Србији зависи управо од ове способности уметника да изаберу локалне урбане стилове и сентименте који су блиски реп сензибилитету и да их реинтерпретирају ослањајући се на хип-хоп поглед на свет, ослобођени притисака доминантних политичких и медијских дискурса у свом матичном друштву.

\section{ЛИТЕРАТУРА:}

Ambrozić, D. (1994) Crna kiša će pasti, Ritam, Vol. V, br. 4, Beograd: Izdavačka zadruga „Ritam”, str. 48-49.

Archer, R. et al. (eds.) (2016) Social Inequalities and Discontent in Yugoslav Socialism, Farnham: Ashgate.

Chang, J. (2005) Can't Stop Won't Stop: A History of the Hip-Hop Generation, New York: St. Martin's Press.

Chang, J. (2009) Ne može da stane, neće da stane - jedna istorija hiphop generacije (preveli Zoran Lojanica i Predrag Vukčević), Beograd: Red Box.

Čikara, A et al. (1989) Betmen, Fantom, Mandrak... Koja! (Po drugi put) - intervju sa Dušanom Kojićem Kojom, Ritam, Vol. I, br. 5 , str. 18-21.

Dimitrijević, B. Globalni turbo-folk, 20. jun 2002., 15. mart 2019., http://www.nin.co.rs/2002-06/20/23770.html

Đurković, M. (2002) Diktatura, nacija, globalizacija, Beograd:

Institut za evropske studije.

Đurković, M. (2004) Ideološki i politički sukobi oko popularne muzike u Srbiji, Filozofija $i$ društvo 25, Beograd: Institut za filozofiju i društvenu teoriju, Univerzitet u Beogradu, str. 271-284.

Gordy, E. (1999) The Culture of Power in Serbia: Nationalism and the Destruction of Alternatives, Pennsylvania: Penn State University Press. 
Hobsbawm, E. (2000) Bandits, London: Weidenfeld \& Nicolson.

Marlow, C. (1984) Brejkdensing, preveo Branko Gavrić, Beograd: Nezavisno izdanje Branka Gavrića.

Matić, Đ. i Đogani H. Leksikon YU mitologije, priredili Andrić, I. i dr. (2005), Beograd: Rende, str. 117-122.

Musić, G. and Vukčević, P. Diesel Power: Serbian Hip Hop from the Pleasure of the Privileged to Mass Youth Culture, in: Hip Hop at Europe's Edge: Music, Agency and Social Change, eds. Miszcynski, M. and Helbig, A. (2017), Bloomington, IN: Indiana University Press, pp. 85-108.

Osumare, H. (2001) Beat Streets in the Global Hood: Connective Marginalities of the Hip Hop Globe, Journal of American and Comparative Cultures 24 (1-2), Bowling Green, $\mathrm{OH}$ : American Culture Association, Bowling Green State University, pp. 171-181.

Quinn, E. (2005) Nuthin'But a G Thang: The Culture and Commerce of Gangsta Rap, New York: Columbia University Press.

Vučetić, R. (2012) Koka-kola socijalizam: Amerikanizacija popularne kulture šezdesetih godina XX veka, Beograd: Službeni glasnik.

Vukčević, P. Mlad (i zdrav) kao rap: I brate, brate, brate - jedna tradicija srpskog hip-hopa (2), 3. јануар 2009., 15. март 2019., http:// www.popboks.com/article/7021

Vukčević, P. Sa ove strane soula - intervju sa Zoranom Simjanovićem, 14. jun 2010., 15. mart 2019., http://www.popboks.com/article/8105

Вукчевић, П. Лични разговор са Иваном Ивановићем Jиісеот, 20. децембар 2012.

Вукчевић, П. Лични разговор са Предрагом Радисавъевићем, 25. фебруар 2013.

\section{Buдеографија:}

Bjelogrlić, D. i dr. (Producenti) i Dragojević, S. (Reditelj) (1998) Rane [igrani film], SR Jugoslavija/Nemačka: Cobra Film Department/Pandora Filmproduktion.

Baljak, J. (Reditelj) (1995) Vidimo se u čitulji [dokumentarni film], SR Jugoslavija: RTV B92.

Јекић, М. (Аутор) и Јанковић, Н. (Редитељ) (1994) Welcome to Дизелдорф [документарни филм], СР Југославија, 5. октобар 2014., 15. март 2019., https://www.youtube.com/watch?v=q7xucYJLEiw

Станојевић, М. (Редитељ), (1992) Таленти 2000-Beat Street [телевизијска емисија], први пут емитована 2. децембра 1992, СР Југославија: РТС.

(2. децембар 1992., 15. март 2019., https://www.youtube.com/ watch?v=SFh6FbozZSw) 
Vukčević, P. Rispekt za iskrene ortake - video intervju sa Ivanom Ivanovićem Juiceom, 23. decembar 2008., 15. mart 2019., http://www. popboks.com/article/6980

Zupanc, G. (Reditelj) (1999) Pećina [dokumentarni film], SR Jugoslavija: Dunav film i Art TV, 22. септембар 2009., 15. март 2019., https://www.youtube.com/watch?v=FcgzK11Z6rY

Ayduографија:

187. (1995) Tamna strana, na Tamna strana [CD] (1997), Beograd: CentroScena/PGP RTS.

Babić, Sneki S. (1991) Sneki Rep, na Hopa-Cupa [LP], Beograd: PGP RTB.

Balašević, Đ. (1989) Sugar Rap (Proces diferencijacije u Kombinatu za proizvodnju i preradu šećerne repe), na Tri posleratna druga [LP], Zagreb: Jugoton.

Belgrade Posse (1994) Time's Up [Demo], 27. januar 2009., 15. mart 2019., https://www.youtube.com/watch?v=B7SSOfe5Pvw

Badvajzer (1987) 24 časa [Demo], 14. oktobar 2017., 15. mart 2019., https://www.youtube.com/watch? $\mathrm{v}=\mathrm{rgIAO}$ - $41 \mathrm{lKkY}$

Badvajzer (1988) God Save The Rap [Demo], 14. oktobar 2017., 15. mart 2019., https://www.youtube.com/watch?v=nAjs3uepNQU

Budweiser (1989) Čuješ li buku [Demo], na Omladina '90 [LP] (1990), Novi Sad: „M” Produkcija Radio Novog Sada.

Dabetić, Annči A. (1992) Noć ludila, na Anđeo za umormu dušu [LP], Beograd: PGP RTB.

Ding Dong (1999) Ćelav sam pa šta?, na South Side [CD] (2000), Beograd: CentroScena.

Disciplina Kičme (1987) Dečija pesma [LP], Beograd: PGP RTB.

Dogg Pound (1993) Niggas Don't Give a Fuck, in Poetic Justice (Music From the Motion Picture) [CD], Los Angeles, CA: Epic Soundtrax.

Du Du A (1983) Hop Ap Du Ap, na Primitivni ples [LP], Beograd: PGP RTB.

Fanky G (1994) Sutra je novi dan, na Samo u snu [Cass], Beograd: MAT/Zmex.

Funky G (2005) U tvojim kolima, na Nedodirliiva [CD], Beograd: City Records.

Juice (2002) Keš kolica, na Hiphopium [CD], Beograd: BK Sound.

Juice (2002) Đuskaj, na Hiphopium [CD], Beograd: BK Sound.

Juice (2002) Zovi me (skit), na Hiphopium [CD], Beograd: BK Sound. Juice 93FU feat. 93FU (2006) Brate minli, na Brate minli [CD], Beograd: City Records. 
Juice 93FU (2006) Uvertira lektira, na Brate minli [CD], Beograd: City Records.

Magic People. (1998) Diesel People [Demo], 28. februar 2011., 15. mart 2019., https://www.youtube.com/watch?v=RgamOKCb5po

Marlon Brutal. (2009) HCZ KCZ [Demo], 6. septembar 2010., 15. mart 2019., https://www.youtube.com/watch?v=WNIZ3Jhp_wQ

The Master Scratch Band (1984) Break War, na Degout [LP], Zagreb: Jugoton.

Musić, G. i Vukčević, P. Đogani šampion (istorija BEEGEE FONKa) - audio intervju sa Hamitom Đogajem Đoganijem, 31. januar 2009., 15. mart 2019., https://soundcloud.com/djapee/djole-shampion Petrović, B. (1981) Đuskaj, na Žur [LP], Ljubljana: ZKP RTVL. Relic feat. Amine. (2004) Just Married [CD Single], Paris: Barclay. Rambo Amadeus (1989) Hoćemo gusle! [LP], Beograd: PGP RTB.

Shwarz. (2010) Dizel Power [Demo], 6. jul 2010., 15. mart 2019., https://www.youtube.com/watch?v=gwG98baHZ88

Tapiri. (1993) Drama, na Milenijum posle - Misterija I [LP], Beograd: PGP RTS

Thug Life (1994) Volume 1 [CD], Los Angeles, CA: Interscope Records.

THCF (2009) Trenerka stil, na Majmun idzuo [CD], Beograd: Tilt.

VIP (2001) Ko će to da plati? [Demo], 10. maj 2011., 15. mart 2019., https://www.youtube.com/watch?v=0XYZIBdJaH8

VIP (2001) Atlantida (Malo para - puno stida), na TILT Volume 1, Beograd: Tilt.

VIP (2002) Moj život, na Bassivity Mixtape - Prvi put [CD], Beograd: Bassivity Music.

Who Is The Best feat. MC Best. (1990) Rap Is My Life [Demo], na Soul Food Music [CD] (2005), Beograd: City Records.

Who Is The Best? (1992) WITB Strikes Again [Demo], na Welcome to Belgrade [CD] (1995), Beograd: ITMM. 
ГОРАН МУСИЋ И ПРЕДРАГ ВУКЧЕВИЋ

\author{
Goran Musić and Predrag Vukčević \\ Universität Graz, Zentrum für Südosteuropastudien, Graz, Austria \\ DIESEL POWER \\ HIP-HOP IN SERBIA FROM SATISFACTION OF THE
PRIVILAGED TO THE MASS YOUTH CULTURE
}

\begin{abstract}
First products of the hip-hop culture reached the Socialist Federative Republic of Yugoslavia in the first half of the 1980s, about the same time they arrived in Western Europe. Still, hip-hop, taken as a rounded lifestyle, did not establish itself as a separate subculture within a thin layer of urban middle-class youth until the early 1990s, with help of satellite television, foreign magazines and bootleg tapes. Some fifteen years after, hip-hip became one of the most widespread youth cultures in Serbia. The objective of this paper is to research the evolution of this process, showing how more and more youth from different social strata have adopted hip-hop while simultaneously adding new local meanings to the imported culture. The article argues for the thesis that the spreading of hip-hop was allowed through acceptance of a diverse local heritage of turbo-folk, funk influences in the pop-music and the urban Roma culture. The rappers' imitation of the dressing styles, slang and diesel subculture attitudes from the early 1990s, which promoted criminal lifestyles, is given as an example.
\end{abstract}

Key words: hip-hop, Yugoslavia, Serbia, turbo-folk, rap, diesel subculture

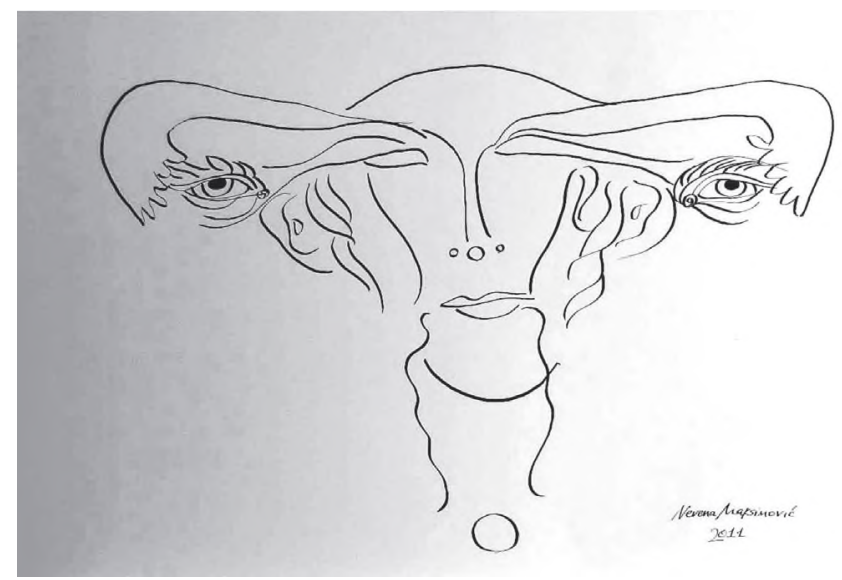

Невена Максимовић, Лепи, цртеж, 2011. 